\title{
Corruption and SME financing structure: the case of Vietnamese manufacturing
}

\author{
Mai Hong Phan \\ Department of Corporate Finance, National Economics University, \\ Hanoi, Vietnam, and \\ Lan Archer \\ Department of Accounting, Finance and Economics, Griffith University, \\ Brisbane, Australia
}

Corruption and SME financing structure

\begin{abstract}
Purpose - Corruption has been evidenced as one of the major factors that drive a firm's dynamics and growth. This study examines the relationship between corruption and financing structure decisions of small and medium-sized enterprises (SMEs) in Vietnam.

Design/methodology/approach - The authors use a longitudinal data set from the Vietnam's SME Survey in the period 2007-2013 and adopt the two-stage least squares method to deal with endogeneity.

Findings - After controlling for endogeneity and firm heterogeneity, the authors find that, overall, corruption does significantly affect the decisions of financing sources. Given that, corruption increases the use of informal debt and decreases the levels of formal debt, owner's equity and retained earnings.

Practical implications - The findings suggest implications for corruption-combating actions and policies. Originality/value - Different from previous studies that either provide evidence of government corruption and a firm's capital structure at the country level or focus on corruption and debt only, we deliver a more comprehensive analysis on the nexus between corruption and various financing sources.
\end{abstract}

Keywords Informal payments, Financing channels, SMEs, Vietnam, 2SLS, Endogeneity

Paper type Research paper

\section{Introduction}

Corruption has been widely acknowledged as an important topic in corporate management, particularly in the growth and development of small and medium-sized enterprises (SMEs) in developing countries (e.g. Le, 2016; Van Vu et al., 2018; Wang and You, 2012). Corruption might facilitate firms to run their businesses more effectively by "greasing the wheels" through easing bureaucratic burdens; however, this might cause a "sand-in-the wheels" impact in hindering a firm's dynamics and growth (Luo, 2005; Vial and Hanoteau, 2010) as well as worsening the quality of public administrative services (Lemma, 2015).

Corruption is considered as the misuse of state power by public officials to earn private gains (Lemma, 2015), which directly affects firm capital structure (Fan et al., 2012). As well, corruption plays a role as a major factor in shaping a country's legal systems, resource allocation and firm behaviour (e.g. Johnson and Mitton, 2003). It has been shown that weaker laws and legitimate regulations are associated with external equity and maturity debt

(C) Mai Hong Phan and Lan Archer. Published in the Journal of Economics and Development. Published by Emerald Publishing Limited. This article is published under the Creative Commons Attribution (CC BY 4.0) license. Anyone may reproduce, distribute, translate and create derivative works of this article (for both commercial and non-commercial purposes), subject to full attribution to the original publication and authors. The full terms of this license may be seen at http://creativecommons.org/ licences/by/4.0/legalcode

Disclosure statement: No potential conflict of interest was reported by the authors.

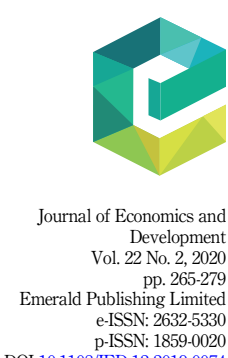

DOI 10.1108/JED-12 $2019-0007$

Received 15 December 2019

Revised 4 February 2020 25 February 2020

Accepted 26 February 2020 
JED

22,2

266

contracts; particularly, more government corruption leads to a higher corporate debt ratio and short debt maturity (Fan et al., 2012). This phenomenon appears to be more uncontrolled in developing countries and hinders the effectiveness of national institutions in enhancing corporate governance. The condition of market imperfection generates strong incentives for state officials to involve in corrupt behaviours (Foellmi and Oechslin, 2007). Accordingly, non-collusive corruption - a behaviour that imposes additional burden on business activity has been common in low-income countries where credit markets remain underdeveloped.

As such, the topic of corruption and financing structure is worth analysing, especially in a developing country setting like Vietnam. On the one hand, earlier studies have shown the importance of capital structure to firm's operations and performance (e.g. Nguyen et al., 2016; Rahaman, 2011). On the other hand, literature has documented the unfavourable institutional environment in developing countries, where Vietnam is a case, through distinctive characteristics, such as inefficient markets, weak financial market or high uncertainty (Chang et al., 2014), which affect a firm's capital structure decisions (Beck, 2007).

From the perspectives of bribe-payers, informal payments reduce their wealth, which serves as a collateral to determine the value of loans they can borrow in the credit markets (Foellmi and Oechslin, 2007). The more demanding the officials are, the lower collateral value the individuals experience. Thus, because of a reduction in collateral, borrowers are not able to obtain loans as much as they expected. The effect of corruptions on borrowing becomes stronger for those who mainly rely on external finance. Further, corruption weakens financial markets by affecting the regulations and increases a firm's business expenses by, such as, increasing costs to obtain loans and operating permits. In the context of Vietnam, although the anti-corruption campaigns have been launched, this issue has still been of concern for firms when doing business (Van Vu et al., 2018). Thus, we suspect if, in some cases, especially in a developing country like Vietnam where corruption has remained widespread and financial markets have been underdeveloped (e.g. Nguyen et al., 2018; Van Vu et al., 2018), there exists a connection between corruption and a firm's financing accessibility. This brings the motivation for us to investigate the impact of corruption on financing structure.

While the extant literature has focused on the link between corruption and external financing, such as short- and long-term debt, little is known about the effects of corruption on a firm's financing structure (formal debt, informal debt, equity and retained earnings). The combination of different financing sources is referred to as the "capital structure puzzle" as proposed by Myers (1984). Our study contributes to the literature by, for the first time, analysing the association between corruption, proxied by informal payments, and financing structure of SMEs in an emerging country like Vietnam. Since the economic and political reforms “Đổi Mór $i$ ” launched in 1986, Vietnam's economy has witnessed a rapid growth and development that contributed to transforming the country from one of the world's poorest to a lower middle-income country (World Bank, 2016). Annual GDP growth rate has been around 6-7\% since the 2000s. For example, GDP growth rate of Vietnam in 2018 reached $7.1 \%$, while GDP per capita increased to US\$2,564 from US\$231 in 1985 (ADB, 2019).

In the context of a rapid growth of the national economy, SMEs have played a crucial role in the socio-economic development, which has been documented in various studies on Vietnam (e.g. Archer, 2019; Nguyen et al., 2016). SMEs contribute to GDP, create employment, produce a large number of products for the society, raise social resources for investments, reduce poverty and develop networks with most sectors (CIEM, 2014). A 2018 report by the Asian Development Bank (ADB) indicates that SMEs account for the majority of Vietnam's total enterprises with approximately 600,000 active businesses, equivalent to $97.6 \%$ of all businesses. This group contributes to estimated $40 \%$ of GDP and over $50 \%$ of total employment. Specifically, they generate $40 \%$ of opportunities to raise the funds to form the investment capital for productions and businesses. 
Regardless of their importance in the development of Vietnam's economy, SMEs have encountered many difficulties that prevent their dynamics and growth. Among others, corruption and access to finance have continued to be major constraints for SMEs (ADB, 2013). As highlighted by Rand and Tarp (2012), over $60 \%$ of Vietnam's firms report informal payments as part of running their businesses, which might affect Vietnam's business environment and the national socio-economic development. Given the constraints in liquidity and credit, the debt ratio of SMEs in Vietnam is considerably low (Rand, 2007) [1]. Due to the difficulties and obstacles in obtaining formal loans, particularly informal expenses such as under-the-table costs or gifts (Nguyen and To, 2019), SMEs consider borrowing loans from informal sources, making this source the most useful channel in supporting the financing of SMEs (Mehnaz and Wimpey, 2007). Hence, we raise a concern about the connection between informal payments and financing structure.

Different from Fan et al. (2012) who provide evidence of government corruption and a firm's capital structure at the country level, we investigate the impacts of corruption on financing structure at the firm level. Going beyond earlier studies (e.g. Du, 2008; Lemma, 2015) that have focused on corruption and debt only, we deliver a more comprehensive analysis on the nexus between corruption and other financing sources, including formal debt, informal debt, owner's equity and retained earnings. To our knowledge, this is the first study on Vietnam that provides fresh evidence of how corruption affects a firm's financing structure decisions.

The analysis of corruption vis-à-vis financing structure relationship is subject to potential endogeneity that arises from the simultaneous effect when informal payments and financing structure decisions jointly depend on unobserved factors captured in the error term. To address the endogeneity issue, this paper adopts the two-stage least squares approach. After controlling for endogeneity and firm heterogeneity, we find that corruption does matter for a firm's financing structure. We provide evidence that corruption decreases the levels of formal debt, owner's equity and retained earnings, while it increases the use of informal debt. The findings suggest that informal payments might erode a firm's internal financing for other investment activities. Policy implications are discussed.

The remainder of this study is organised as follows. Section 2 reviews the literature on corruption and financing. Section 3 outlines econometric strategy. Section 4 provides data source and descriptive statistics. Section 5 reports empirical results and discussion. Section 6 concludes.

\section{Literature review}

It is firmly believed that credit is a crucial issue of operating and running enterprises (e.g. Archer, 2019; Nguyen and Phan, 2015). "Without adequate access to financing, the staying power of the business and its potential for growth is jeopardised" (Rahaman, 2011, p. 709). Firms are likely to have access to external credit as their self-funding or internal capital is often insufficient for their operation, especially in the start-up and strong growth periods (Oncioiu, 2012). Particularly for SMEs, they demand external financing access to run businesses, create new products, enhance employees' knowledge and skills and equip more production facilities (Atieno, 2009). In a cross-country study, Beck et al. (2008) find that small firms are heavily reliant on internal and informal capital but slightly dependent on formal loans than are larger firms.

Financial theory suggests that corporate governance, especially debt financing or capital structure, is potentially determined by firm-specific factors, legal and institutional environment and economic situation (Harris and Raviv, 1991). Accordingly, in countries with a strong law enforcement mechanism protecting creditor rights as well as a perfect financial market without information asymmetry, borrowers are more likely to have access to 
JED

22,2

268

finance because lenders can easily control risk and mitigate the expected default loss. Continuing the debate, Rajan and Zingales (1995) emphasise the major institutional differences and their potential effect on a firm's financing structure. The authors show that the institutional environment, characterised by the tax and bankruptcy code, the market for corporate control and the historical roles of banks and securities markets, affects the withincountry cross-sectional correlation between leverage and firm profitability. In the scope of this research, we do not aim to compare the availability of internal and external credit, but to examine the influence of corruption on financing patterns.

Regarding the relationship between corruption and debt, Butler et al. (2009) find a strong relationship between state corruption and municipal bond sales and underwriting. Generally, the authors provide evidence of a strong effect of corruption and political connections on financial market outcomes. As such, the higher level of state corruption causes higher credit risk and higher bond yields. The authors find a negative effect of corruption on bond ratings, suggesting a higher default risk. Likewise, Ciocchini et al. (2003) examine the relationship between corruption and borrowing costs for governments and firms, thus highlighting that countries with higher corruption levels must pay a higher risk premium when issuing bonds. Liu et al. (2015) emphasise that corruption distorts the allocation of financial resources, which might affect the positive effects of equity market liberalisation on firm operations.

In the same vein, Jain et al. (2017) find a significant effect of corruption on national financial markets through the adverse relation with liquidity and foreign portfolio investment. In other words, a higher level of corruption leads to a lower investment of foreign portfolio into a country. It is viewed that foreign investors tend to mainly invest in economies with transparent business environments or those relatively free of corruption. The authors explain an indirect channel of corruption effect on financial markets through the impact on asymmetric information and investor uncertainty [2]. These issues result in higher adverse selection costs that, in turn, impact foreign portfolio investment and other related transactions. Thus, corruption incurs an indirect effect on foreign investment through discouraging investors from participating in the markets due to information asymmetry.

In a cross-country study, Fan et al. (2012) show that corruption has a significant effect on firm capital structure decisions. As such, in the case of more corruption of the public sector, firms tend to use relatively more debt than equity, in which long-term debt is more preferred than short-term debt. Similarly, Lemma (2015) analyses the impact of corruption on firm finance and ownership patterns of firms in African countries. The author provides evidence of the importance of corruption in forming debt financing and ownership structure and finds that perceived corruption affects a firm's borrowing decisions by increasing the level of shortterm debt and decreasing the level of long-term debt. This evidence confirms the findings by Du (2008) who shows that higher levels of corruption leads to higher levels of short-term leverage and lower levels of long-term leverage.

In another aspect, De Jong et al. (2008) emphasise that better law enforcement and legal systems, particularly through reducing the level of corruption, tend to force borrowers to abide by their debt contracts, thus better protecting shareholders and creditors. The authors find that better legal systems and regulations increase growth opportunities, liquidity and profitability and that firms tend to use more debt in countries with a better law enforcement system or lower corruption level and a more stable economy. In the same vein, Du (2008) documents that firms in countries with weaker legal enforcement systems experience higher levels of corruption through higher ownership concentration and controlling block shareholding. As well, under a corrupt government, banks need to bribe government bureaucrats to gain access to government protection in banking operations. 
In sum, the reviewed literature has been limited to providing a comprehensive analysis on corruption and financing structure. Most of previous studies have focused on corruption and debt financing, which remains a gap regarding the nexus between corruption and other financing sources. Thus, our study is expected to bridge the gap by analysing the impacts of corruption on financing structure decisions of firms in the context of a developing country like Vietnam.

\section{Econometric strategy}

This study relies on the pecking order theory (Myers, 1984) - a core leading theory of corporate finance - to develop model specifications. The main idea of this theory postulates that firms prioritise their use of financing sources because of the adverse selection problem: first using internal financing, then debt and last equity. Thus, following the discussion previously, we suspect if a firm's financing structure, consisting of formal debt, informal debt, owner's equity and retained earnings, is significantly driven by corruption.

Literature has highlighted the presence of endogeneity of corruption on financing decisions (e.g. Du, 2008; Lemma, 2015). One potential reason for endogeneity might derive from the simultaneous determination within the system of equations, particularly the decisions to make informal payments and use financing sources jointly depend on other unobserved factors captured in the error term. For example, Du (2008) argues that the dominance of bank financing appears to generate a close connection between firms and government officials, which increases the perception of a high degree of corruption. Thus, endogeneity might arise from unobserved factors and needs to be addressed.

To deal with the endogeneity issue, we adopt the two-stage least squares (2SLS) method on a panel data set, following Wooldridge (2010). The main idea of this method is as follows. In the first stage, the random-effects probit regression is run to identify determinants of credit access of SMEs. This regression is selected as we explore time-invariant variables, including the gender of the owner, the educational level and the area where a firm is located. The entity's error term is supposed not to be correlated with the independent variables, which allows timeinvariant variables to play a role as predictors (Breusch et al., 2011; Tran and Santarelli, 2013). As discussed previously, corruption is a potentially endogenous variable in association with a firm's financing accessibility; thus, we obtain fitted values of corruption from the first stage and use it in the second stage as our instrumented key independent variable to correct for endogeneity. As such, in the second stage, we run a regression of financing structure including formal debt, informal debt, owner's equity and retained earnings - on instrumented corruption and a set of control variables. This method is efficient in dealing with the endogeneity issues of corruption and measurement error (Baum et al., 2007). As well, this strategy allows us to yield unbiased and reliable estimates of the nexus between corruption and financing structure.

In the first stage, Corr $_{i t}$ is regressed on a set of independent variables and instruments, and then fitted values of Corr $_{i t}$ are obtained to use in the second stage. The equation is given as:

$$
\operatorname{lnCorr}_{i t}=\alpha_{0}+\alpha_{1} X_{i t}+\alpha_{2} Z_{i t}+\vartheta_{i t}
$$

where $\operatorname{lnCorr} i t$ denotes the logarithm of informal payments of firm $i$ at time $t ; \alpha_{1}$ and $X_{i t}$ are the vector of coefficients associated with $X_{i t}$ and $Z_{i t}$, respectively; $\alpha 0$ is the intercept or constant term; $\vartheta_{i t}$ is the composite error that consists of the individual specific unobserved effect and the classical random error term. Variable description is further provided in the next section.

Following previous studies (e.g. Rand and Tarp, 2012; Van Vu et al., 2018), this study uses informal payment as a proxy for a firm's corruption. To conduct the key independent variable "corruption", we use the following questions in the survey tool that was used to interview a 
JED

22,2

firm's managerial respondent: "Do you have to pay informal/communication fees?" and "Approximately how much did you pay in total last year?".

We also follow literature (e.g. Nguyen and To, 2019; Pham and Talavera, 2018; Rand and Tarp, 2012) to include a set of control variables $X_{i t}$ to control for firm and owner characteristics, which consists of assets (log.), revenue (log.), firm age, networking, Certificate of Land Use Right (CLUR), credit history, accounting book, gender of owner and age of owner. Time and location effects are captured in an instrument (inspection).

$Z_{i t}$ is a set of instrumental variables, including inspection, time to deal with government regulations and respondent's perception of the Law on Enterprise. Following earlier studies (Wang and You, 2012), this study uses a set of instruments, including inspection, time to deal with government regulations and respondent's perception of the Law on Enterprise. The instruments should be correlated with informal payments but uncorrelated with a firm's financing decisions. Regarding the first instrument inspection, this variable is used to capture the engagement of government officials in business activities (Rand and Torm, 2012), thus it might lead to a higher probability that firms bribe the bureaucrats to ease their investigation. Rand and Torm (2012) find no significant relationship between inspection and access to credit. Thus, we argue that inspection has a significant effect on corruption (our endogenous variable) but no effect on credit access (our dependent variable). Second, we select time to deal with government regulations to be an instrument because this variable is associated with corruption: the more time that firms spend dealing with government regulations, the more likely they bribe the bureaucrats to speed up or smooth the progress, especially in developing countries (Wang and You, 2012). Third, we consider manager's perception of the Law on Enterprise as another instrument for the reason that lack of knowledge on businesses might increase the bribe behaviour of firms to "get things done" or to build up relationships with public officers to facilitate their operations (Tonoyan et al., 2010). The relevance, validity and power of the instruments are presented in the next section.

In the second stage, the main idea is to use the fitted values obtained from the first stage as an instrumented Bribe ${ }_{i t}^{I V}$ variable that corrects for endogeneity. Extant literature has documented the importance of financing channels in a firm's business operations (e.g. Archer, 2019; Lemma, 2015; Liu et al., 2015). This study captures SME financing patterns by taking the logarithm of formal liabilities, informal liabilities, owner's equity funding and retained earnings. We rely on financing-related information specified in the questionnaire to construct our key dependent variables. The equations are formulated as:

Corruption and formal debt:

$$
\ln \mathrm{FD}_{i t}=\beta_{0}+\beta_{1} \ln _{\operatorname{lorr}}^{I V}+\beta_{2} X_{i t}+\vartheta_{i t}
$$

Corruption and informal debt:

$$
\ln \mathrm{ID}_{i t}=\beta_{0}+\beta_{1} \ln \operatorname{Corr}_{i t}^{I V}+\beta_{2} X_{i t}+\vartheta_{i t}
$$

Corruption and owner's equity:

$$
\ln \mathrm{OD}_{i t}=\beta_{0}+\beta_{1} \operatorname{lnCorr}_{i t}^{I V}+\beta_{2} X_{i t}+\vartheta_{i t}
$$

Corruption and retained earnings:

$$
\operatorname{lnRE} E_{i t}=\beta_{0}+\beta_{1} \operatorname{lnCorr}_{i t}^{I V}+\beta_{2} X_{i t}+\vartheta_{i t}
$$

where financing structure is represented through formal debt (log.) $\operatorname{lnFD}{ }_{i t}$, informal debt (log.) $\ln \mathrm{D}_{i t}$, owner's equity (log.) $\ln \mathrm{OD}_{i t}$ and retained earnings (log.) $\ln \mathrm{RE}_{i t}$ of firm $i$ in year $t$, 
respectively; $\beta_{O}$ is the constant term; $\beta_{1}$ captures the influences of instrumented corruption on financing structure; $\beta_{2}$ is the vector of coefficients associated with $X_{i t}$.

\section{Data}

\subsection{Data source}

This study employs data from the Survey of Small and Medium Scale Manufacturing Enterprises in Vietnam, conducted biennially from 2005 to 2015 in ten provinces across Vietnam as a project collaboration between Vietnam and Denmark [3]. The Survey was implemented through direct interviews with a firm's managerial representative to collect data and information of the private sector, particularly SMEs. Data cover all firm-related aspects, including general characteristics, firm history, production, sales structure and export, costs and materials, investments and financing, taxes and informal payments, employment, environment, networks and economic constraints and potentials. There were around 2,500 surveyed firms in each round. This study excludes data in the 2005 and 2015 rounds due to limited information on the formal and informal debt. After processing data, we obtain a panel data set of 5,252 observations in the period 2007-2013.

Table 1 shows the share of SMEs by province and size over year. As reported, the surveyed firms in Ho Chi Minh City account for the highest proportion of around $24 \%$, followed by those in Ha Tay and Nghe An (14\%, on average), Ha Noi (11\%) and Phu Tho $(10 \%)$. By size, micro firms account for the major proportion on the range from $66 \%$ to $72 \%$ over year. Medium-sized firms share the lowest percentage of surveyed firms with less than $1 \%$.

\subsection{Descriptive statistics}

Table 2 shows the description of variables and data summary statistics. As reported, the owner's equity is the biggest-sized financing source of firms (13.69 in logs, on average), followed by retained earnings (11.70 in logs, on average). As for borrowing, formal and informal liabilities range from, on average, 3.21 to 3.64 in logs, respectively, with the dominance of informal debt. The average amount of informal costs incurs at 2.66 in logs. On

\begin{tabular}{lcccc}
\hline \multicolumn{1}{c}{2007} & 2009 & 2011 & 2013 \\
\hline By province & & & \\
Ha Noi & $290(11.2)$ & $296(11.2)$ & $291(11.5)$ & $283(11.2)$ \\
Phu Tho & $248(9.6)$ & $266(10.1)$ & $254(10.1)$ & $261(10.3)$ \\
Ha Tay & $391(15.1)$ & $383(14.5)$ & $347(13.8)$ & $342(13.5)$ \\
Hai Phong & $204(7.9)$ & $225(8.51)$ & $221(8.8)$ & $200(7.9)$ \\
Nghe An & $356(13.7)$ & $370(14.0)$ & $351(13.9)$ & $343(13.5)$ \\
Quang Nam & $172(6.6)$ & $167(6.3)$ & $165(6.5)$ & $166(6.5)$ \\
Khanh Hoa & $92(3.5)$ & $96(3.6)$ & $99(3.9)$ & $91(3.6)$ \\
Lam Dong & $87(3.4)$ & $72(2.7)$ & $78(3.1)$ & $84(3.3)$ \\
Ho Chi Minh City & $621(23.9)$ & $626(23.8)$ & $590(23.4)$ & $627(24.7)$ \\
Long An & $135(5.2)$ & $133(5.0)$ & $126(5.0)$ & $138(5.4)$ \\
By size & & & \\
Micro & $1,716(66.1)$ & $1,763(66.9)$ & $1,731(68.6)$ & $1,817(71.7)$ \\
Small & $856(33.0)$ & $861(32.7)$ & $780(30.9)$ & $710(28.0)$ \\
Medium & $24(0.9)$ & $10(0.4)$ & $11(0.5)$ & $8(0.3)$ \\
Total & $2,596(100.0)$ & $2,634(100.0)$ & $2,522(100.0)$ & $2,535(100.0)$ \\
Source(s): Authors' calculation from the SME Survey & & \\
\hline
\end{tabular}

Corruption and SME financing structure

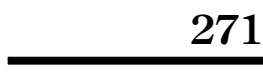




\begin{tabular}{|c|c|c|c|c|c|}
\hline Variable & Description & Mean & SD & Min & Max \\
\hline \multicolumn{6}{|l|}{ Dependent variable } \\
\hline Formal debt (log.) & $\begin{array}{l}\text { The logarithm of formal liabilities of firms at } \\
\text { year-end }\end{array}$ & 3.211 & 5.409 & 0.000 & 18.585 \\
\hline Informal debt (log.) & $\begin{array}{l}\text { The logarithm of informal liabilities of firms } \\
\text { at vear-end }\end{array}$ & 3.637 & 5.185 & 0.000 & 17.737 \\
\hline Owner's equity (log.) & $\begin{array}{l}\text { The logarithm of owner's equity funding at } \\
\text { year-end }\end{array}$ & 13.685 & 1.762 & 6.551 & 19.566 \\
\hline $\begin{array}{l}\text { Retained earnings } \\
\text { (log.) }\end{array}$ & $\begin{array}{l}\text { The logarithm of net profits of firms at year- } \\
\text { end }\end{array}$ & 11.703 & 1.785 & 0.000 & 19.523 \\
\hline \multicolumn{6}{|l|}{ Independent variable } \\
\hline $\begin{array}{l}\text { Corruption amount } \\
\text { (log.) }\end{array}$ & $\begin{array}{l}\text { The logarithm of informal payments at year- } \\
\text { end }\end{array}$ & 2.661 & 3.790 & 0.000 & 15.450 \\
\hline Assets (log.) & $\begin{array}{l}\text { Firm size, measured by the logarithm of the } \\
\text { assets at year-end }\end{array}$ & 13.780 & 1.757 & 6.908 & 19.567 \\
\hline Revenue (log.) & The logarithm of revenue at year-end & 13.407 & 1.885 & 0.000 & 22.836 \\
\hline Firm age & $\begin{array}{l}\text { The difference between the surveyed year and } \\
\text { the year of establishment }\end{array}$ & 15.864 & 10.377 & 1.000 & 72.000 \\
\hline Networking (Yes = 1) & $\begin{array}{l}\text { Dummy variable, coded } 1 \text { if a firm is a member } \\
\text { of at least one business association, } \\
0 \text { otherwise }\end{array}$ & 0.088 & 0.283 & 0.000 & 1.000 \\
\hline CLUR $($ Yes $=1)$ & $\begin{array}{l}\text { Dummy variable, coded } 1 \text { if a firm holds a } \\
\text { Certificate of Land Use Right (CLUR), } \\
0 \text { otherwise }\end{array}$ & 0.536 & 0.499 & 0.000 & 1.000 \\
\hline $\begin{array}{l}\text { Credit history } \\
(\text { Yes }=1)\end{array}$ & $\begin{array}{l}\text { Dummy variable, coded } 1 \text { if a firm had } \\
\text { borrowed from the main creditor before, } \\
0 \text { otherwise }\end{array}$ & 0.301 & 0.459 & 0.000 & 1.000 \\
\hline $\begin{array}{l}\text { Accounting book } \\
(\text { Yes }=1)\end{array}$ & $\begin{array}{l}\text { Dummy variable, coded } 1 \text { if a firm maintained } \\
\text { a formal accounting book in accordance with } \\
\text { government guidelines, } 0 \text { otherwise }\end{array}$ & 0.320 & 0.467 & 0.000 & 1.000 \\
\hline Gender $($ Male $=1)$ & $\begin{array}{l}\text { Dummy variable, coded } 1 \text { if the owner is male, } \\
0 \text { if female }\end{array}$ & 0.662 & 0.473 & 0.000 & 1.000 \\
\hline Owner's age & $\begin{array}{l}\text { The difference between the surveyed year and } \\
\text { the year of birth of the firm's owner or } \\
\text { manager }\end{array}$ & 46.911 & 10.408 & 17.000 & 94.000 \\
\hline \multicolumn{6}{|l|}{ Instrumental variables } \\
\hline Inspec & $\begin{array}{l}\text { Number of times that a firm was inspected last } \\
\text { year by government officials for policy } \\
\text { compliance, technical compliance and others, } \\
\text { averaged by year and province }\end{array}$ & 0.924 & 1.067 & 0.000 & 3.805 \\
\hline $\begin{array}{l}\text { Time to deal with } \\
\text { government } \\
\text { regulations }\end{array}$ & $\begin{array}{l}\text { Percentage of management's working time } \\
\text { spent on dealing with government regulations } \\
\text { and officials (including taxes, permits, } \\
\text { licenses, business and trade regulations) }\end{array}$ & 2.540 & 8.556 & 0.000 & 99.000 \\
\hline Perception & $\begin{array}{l}\text { Perception of managerial respondents on the } \\
\text { Law on Enterprise (1- Good, 2- Average, 3- } \\
\text { Poor, 4- No knowledge) }\end{array}$ & 2.945 & 1.033 & 1.000 & 4.000 \\
\hline
\end{tabular}

Table 2.

Variables and descriptive statistics
Note(s): This table presents variable description and descriptive statistics based on authors' calculations from the SME Survey

average, the logarithm of total assets is 13.78 , while the average revenue reaches 13.41 in logs. The average age of firms in the sample is nearly 16 years since their establishment. In all, $8.8 \%$ of firms are member of at least one business association. The share of firms holding the Certificate of Land Use Right is $53.6 \%$. In the sample, we observe around $30 \%$ of firms 
borrowing from the main creditor before, referring to their credit history with the lenders. On average, $32 \%$ of firms in the sample maintained a formal accounting book in accordance with government guidelines. Regarding owner's characteristics, $66.2 \%$ of firms are run by male entrepreneurs and the owner's average age is 47 years.

With regard to instrumental variables, we report that firms experience, on average, almost one time being inspected a year by government officials for policy compliance, technical compliance and others. Meanwhile, firms spent, on average, $2.5 \%$ of management's working time spent on dealing with government regulations and officials (including taxes, permits, licenses, business and trade regulations). The perception of managerial respondents on the Law on Enterprise is, on average, at the poor level.

Table 3 reports financing structure between firms that had to pay informal costs and those that did not in Panel A and purposes of making informal payments in Panel B. In general, $34.27 \%$ of firms had to pay informal payments when running their businesses. The $t$-statistics are reported to show the difference of mean between the two groups (those with and without informal payments) in column [3], significant at $1 \%$ level, suggesting a rejection of the null hypothesis that the difference of average financing structure (formal debt, informal debt, owner's equity and retained earnings) between firms that paid informal costs (group [2]) and those that did not (group [1]) is not greater than 0 . This suggests that between the two groups, firms paying informal costs appear to maintain higher levels of the four financing sources (formal borrowing, informal borrowing, owner's equity and retained earnings) than their counterparts.

Panel B reports the shares of firms engaging in informal-payment activities by their purposes. Accordingly, a common purpose for firms to make informal payments is to get connected to public services, accounting for $24.11 \%$, followed by those making informal payments to deal with taxes and tax collection $(23.6 \%)$ and to gain government contracts or

\begin{tabular}{|c|c|c|c|c|c|}
\hline & \multicolumn{2}{|c|}{$\begin{array}{c}\text { Firms without } \\
\text { informal payments }\end{array}$} & \multicolumn{2}{|c|}{$\begin{array}{l}\text { Firms with informal } \\
\text { payments }\end{array}$} & \multirow{2}{*}{$\begin{array}{c}t \text {-stat. between } \\
{[2] \text { and }[1]} \\
{[3]}\end{array}$} \\
\hline & Mean & SD & Mean & $\mathrm{SD}$ & \\
\hline \multicolumn{6}{|c|}{ Panel A: Informal payments and financing structure } \\
\hline Formal debt (log.) & 2.704 & $(0.084)$ & 4.181 & $(0.143)$ & $9470 * * *$ \\
\hline Informal debt (log.) & 2.821 & $(0.079)$ & 5.200 & $(0.137)$ & $16.173^{* * * *}$ \\
\hline Owner's equity (log.) & 13.274 & $(0.030)$ & 14.471 & $(0.035)$ & $24.687 * * *$ \\
\hline Retained earnings (log.) & 11.384 & $(0.028)$ & 12.313 & $(0.045)$ & $18477 * * *$ \\
\hline Observations & 3.452 & & 1.800 & & \\
\hline
\end{tabular}

Panel B: Purpose of making informal payments

To get connected to public services

$434[24.11]$

To get licenses and permits

To deal with taxes and tax collection

To gain government contracts or public procurement

To deal with customs, imports and/or exports

$102[5.67]$

$425[23.61]$

$203[11.28]$

$54[3.00]$

Others

Total

$582[32.33]$

1,800 [100.00]

Note(s): This table reports statistics of informal payments and financing structure in Panel A and purposes of making informal payments in Panel B. In Panel A, mean values are reported in columns [1] and [2], followed by standard deviations in parentheses. The $t$-statistics are reported in column [3] by using $t$-test to test the null hypotheses $H 0$ : difference of mean is not greater than 0 . *** denotes the level of significance at $1 \%$. In Panel B cell values represent the number of observations, followed by percentages in brackets

Corruption and SME financing structure

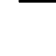


JED

22,2

public procurement $(11.3 \%)$. Less than $6 \%$ of firms report informal payments for obtaining licenses and permits $(5.67 \%)$ and dealing with customs, imports and/or exports (3\%).

\section{Results and discussion}

\subsection{Endogeneity}

We perform tests of endogeneity in Table 4 to show that corruption is indeed endogenous and needs to be addressed. We also prove the relevance and validity of the instruments in addressing the endogeneity of corruption. First, as shown in Table 4, the Hausman test of endogeneity shows the significant statistics in all four specifications ( $\phi$-values $=0.000$ ), rejecting the null hypothesis that the specified independent variable (corruption) is exogenous. Thus, the presence of endogenous corruption needs to be addressed to yield unbiased estimates. Second, in all specifications, the Sargan test of over-identification shows the insignificant statistics ( $p$-values $>0.10$ ), implying that we cannot reject the null hypothesis that the instruments are valid or that they are uncorrelated with the error term. As such, the Sargan test confirms the validity of our instruments in correcting for endogeneity. Third, the LM test of under-identification shows significant statistics with $p$-values $=0.000$, suggesting a rejection of the null hypothesis that the equation is under-identified or that the instruments are not relevant. Hence, this test confirms the relevance of our instruments as well as the exact identification of the specifications. Last, the significant Cragg-Donald Wald $F$-statistics suggests a rejection of the null hypothesis that the instruments are correlated with the endogenous variable but only weakly. In other words, the Cragg-Donald test of weak identification test confirms an adequate power of our instruments in addressing endogeneity.

\subsection{Main findings}

Table 5 reports the empirical results of the nexus between corruption and financing patterns of SMEs in Vietnam. After controlling for endogeneity and firm heterogeneity, we show interesting findings that corruption has negative impacts on formal debt, owner's equity and retained earnings (columns [1], [3] and [4], respectively) and a positive effect on the level of informal debt (column [2]). Holding other factors unchanged, a 1\% increase of informal payments leads to a decrease of using formal debt by $0.97 \%$ (column [1]), followed by a decrease of owner's equity and retained earnings by $0.02 \%$ (column [3]) and $0.12 \%$ (column [4]), respectively.

Adversely, a 1\% increase of informal payments results in an increase of the use of informal debt by $1.07 \%$ (column [2]).

\begin{tabular}{|c|c|c|c|c|}
\hline & $\begin{array}{c}\text { Formal debt } \\
{[1]}\end{array}$ & $\begin{array}{c}\text { Informal debt } \\
{[2]}\end{array}$ & $\begin{array}{c}\text { Owner's } \\
\text { equity } \\
{[3]}\end{array}$ & $\begin{array}{c}\text { Retained } \\
\text { earnings } \\
{[4]}\end{array}$ \\
\hline Hausman test of endogeneity $\left(j^{2}\right)$ & $15.792[0.000]$ & $9.363[0.002]$ & $5.106[0.024]$ & $17.237[0.000]$ \\
\hline $\begin{array}{l}\text { Sargan } x^{2} \text { statistic (Over-identification } \\
\text { test) }\end{array}$ & $0.074[0.785]$ & $0.794[0.373]$ & $0.364[0.546]$ & $0.015[0.902]$ \\
\hline $\begin{array}{l}\text { Anderson canon. corr. LM statistic } \\
\text { (under-identification test) }\end{array}$ & $27.010[0.000]$ & $22.900[0.000]$ & $45.035[0.000]$ & $85.173[0.000]$ \\
\hline Cragg-Donald Wald F-statistic (weak & $13.560[0.000]$ & $11.485[0.000]$ & $22.714[0.000]$ & $43.406[0.000]$ \\
\hline
\end{tabular}

Table 4.

Endogeneity of corruption
Note(s): This table reports endogeneity tests of corruption on financing structure from four given specifications using 2 SLS. $P$-values are in brackets. The instruments are included in all four specifications. Year and location effects are included. The number of observations is 5,252 


\begin{tabular}{|c|c|c|c|c|}
\hline Variable & $\begin{array}{c}\text { Formal debt } \\
{[1]}\end{array}$ & $\begin{array}{c}\text { Informal debt } \\
{[2]} \\
\end{array}$ & $\begin{array}{c}\text { Owner's equity } \\
\text { [3] } \\
\end{array}$ & $\begin{array}{c}\text { Retained earnings } \\
{[4]} \\
\end{array}$ \\
\hline Corruption amount (log.) & $-0.968 * * *(0.299)$ & $1.070 * * *(0.350)$ & $-0.022 * *(0.010)$ & $-0.116^{* * *}(0.031)$ \\
\hline Assets (log.) & $0494 * * *(0.145)$ & $-0.304 *(0.165)$ & $1.039 * * *(0.006)$ & $0.097 * * *(0.021)$ \\
\hline Revenue (log.) & $0.234 * * *(0.080)$ & $-0.007(0.089)$ & $-0.006^{*}(0.003)$ & $0.852 * * *(0.013)$ \\
\hline Firm age & $-0.004(0.013)$ & $-0.013(0.015)$ & $0.000(0.001)$ & $-0.002(0.002)$ \\
\hline Networking $($ Yes = 1) & $1.036 * * *(0.395)$ & $-1.127 * * *(0.427)$ & $-0.019(0.018)$ & $0.020(0.073)$ \\
\hline CLUR $($ Yes = 1) & $0.039(0.209)$ & $-0.223(0.228)$ & $0.011(0.009)$ & $0.047(0.037)$ \\
\hline Credit history (Yes $=1)$ & $3.586 * * *(0.217)$ & $1849 * * *(0.237)$ & $-0.074 * * *(0.009)$ & $0.008(0.039)$ \\
\hline $\begin{array}{l}\text { Accounting book } \\
(\text { Yes = 1) }\end{array}$ & $0.260(0.369)$ & $0.099(0.400)$ & $0.007(0.016)$ & $0.000(0.068)$ \\
\hline Gender $($ Male $=1)$ & $-0.184(0.254)$ & $-0.062(0.274)$ & $0.004(0.011)$ & $0.033(0.047)$ \\
\hline Owner's age & $-0.024 *(0.014)$ & $0.028 *(0.015)$ & $0.000(0.001)$ & $0.001(0.003)$ \\
\hline Location effects & Yes & Yes & Yes & Yes \\
\hline Year effects & Yes & Yes & Yes & Yes \\
\hline
\end{tabular}

Corruption and SME financing structure

Note(s): This table reports the main results of the impacts of corruption on financing structure based on four given specifications. 2SLS estimations are applied. Cell values represent coefficients of individual variables, followed by standard errors in parentheses. The instruments are included in the four specifications. *, ** and $* * *$ denote the levels of significance at $10 \%, 5 \%$ and $1 \%$, respectively. The number of observations is 5,252

Table 5.

Impacts of corruption on financing structure

The results confirm the importance of corruption in shaping a firm's debt financing, as highlighted by Lemma (2015). However, conducting a multi-country study, Lemma argues that firms in countries with higher levels of perceived corruption are likely to remain a lower level of debt relative to equity, a higher level of short-term debt and a lower level of long-term debt. Partly consistent with Lemma's findings, we provide evidence that corruption lowers the use of formal debt, owner's equity and retained earnings. Instead, those paying a high level of informal costs tend to use more informal debt. One possible explanation as indicated by Barslund and Tarp (2008) is that in the context of Vietnam, business activities related to production and asset accumulation rely on formal loans, while those associated with consumption smoothening due to an agent's shocks or unforeseen events mostly use informal loans. As such, we argue that as for SMEs, formal loans are used for planned business operations and investments, while informal loans are likely used to smooth their businesses.

In this study, we consider owner's equity and retained earnings as a firm's internal funding [4]. As stated by $\mathrm{Ou}$ and Haynes (2006), internal funding is widely used by small business owners as one of the most major financing sources for small firms' operations, especially when they encounter formal credit constraints [5]. According to the pecking order theory discussed previously, we provide an explanation regarding the negative nexus between corruption and internal funding (owner's equity and retained earnings) that firms would spend this source of financing on their business operations and investments rather than on unexpected or unforeseen activities like informal payments, such as under-the-table costs. Further, as discussed previously, making informal payment reduces an agent's wealth (Foellmi and Oechslin, 2007); thus, in the case of our study, corruption erodes internal financing sources, including owner's equity and retained earnings.

In addition, we argue that internal funding is supposed to not spend on informal payments in order to ensure an appropriate equity ratio in the financing process, which explains the negative relationship between corruption and internal financing. Ou and Haynes (2006) show that owner's equity, together with physical assets, is important in forming a firm's collateral when they apply for formal credit. Thus, the higher the level of owner's equity, the higher likelihood that firms have their loan applications approved, especially in the context of a developing country like Vietnam where the financial systems remain underdeveloped and 
JED

22,2

banks strongly consider a firm's collateral before making any lending decision (Rand, 2007). As a result, internal equity in the form of collateral is one of decisive factors that enhances the chance of obtaining debt financing.

This study finds significant relationships between control variables and financing structure. Larger firms raise more formal debt by $0.49 \%$ (column [1]), more owner's equity by $1.04 \%$ (column [3]) and more retained earnings by $0.1 \%$ (column [4]), but less informal debt by $0.3 \%$ (column [2]). This finding is consistent with Whited and $\mathrm{Wu}(2006)$ who find that large firms are more likely to have credit access relative to their small counterparts. As well, our finding is in line with Beck (2007) that small firms tend to use informal financing sources.

The positive and significant coefficients of revenue reported in columns [1] and [4] suggest that firms with a higher revenue level use more formal debt by $0.23 \%$ and more retained earnings by $0.85 \%$. Adversely, there is a negative and significant relationship between revenue and the use of owner's equity (column [3]). Meanwhile, firms having a membership in at least one business association remain at a higher level of formal debt (column [1]) but at a lower level of informal debt (column [2]). As indicated by Pham and Talavera (2018), membership of a business association helps firms spread their existence and reputation, which leads to a higher chance of obtaining formal loans or having better loan terms.

Firms having a credit history with their creditors use more formal and informal debt. Holding others constant, firms with credit history remain at a higher level of formal debt by $3.59 \%$ (column [1]) and of informal debt by $1.85 \%$ (column [2]). Having a credit history with lenders might save transaction costs for either lenders when screening the borrower's loan applications or borrowers when preparing loan applications given the requirements and process by the lenders. Thus, credit history has a positive connection with external debt, and then decreasing the use of owner's equity.

Last, we find a significant coefficient of owner's age: this variable is negative in association with formal debt (column [1]) but has a positive relationship with informal debt (column [2]). It suggests that firms owned by older entrepreneurs tend to borrow less in the formal credit markets but more in the informal markets. This is possibly because older entrepreneurs, when seeking external financing, tend to avoid complicated requirements and conditions by formal lenders; thus, they prefer using informal financing because of its straightforwardness.

We find no significant evidence of the relationship between a set of control variables (firm age, CLUR, accounting book and gender of owner) and financing patterns in all four specifications.

\section{Conclusion}

The contributions of this study are twofold. First, we shed light on the association between corruption, proxied by informal payments, and financing structure of SMEs in an emerging country like Vietnam. Second, we go beyond the extant literature by providing a comprehensive analysis on how corruption affects four financing components: formal debt, informal debt, owner's equity and retained earnings. We use panel data from the SME Survey in Vietnam to investigate the impacts of corruption on SME financing sources in the context of Vietnam. By applying the two-stage least squares econometric method, we find that corruption negatively and significantly affects a firm's formal debt, owner's equity funding and retained earnings; but positively and significantly affects informal debt. This finding might imply that SMEs tend to use informal credit to pay informal costs when running businesses. On the one hand, corruption might "grease the wheels" in facilitating firms to do business (Vial and Hanoteau, 2010); however, on the other hand, paying informal costs might erode a firm's internal financing for their long-term investment activities, such as innovation (Luo, 2005). Thus, corruption-combating policies and actions might be considered, as suggested by Van Vu et al. (2018), with the purpose to establish a favourable business 
environment for SMEs. Our study opens a room for future research to examine the link among corruption, financing sources and innovation of SMEs in an emerging country.

\section{Notes}

1. As a vulnerable group with low survival rate, SMEs often suffer from credit-related issues, such as shortage of credit, credit rationing or high loan interest rate.

2. Asymmetric information refers to the situation in which some market participants get to know more information on the levels of risk and expected returns of an asset than others.

3. Ten provinces consist of Ha Noi, Phu Tho, Ha Tay, Hai Phong, Nghe An, Quang Nam, Khanh Hoa, Lam Dong, Ho Chi Minh City and Long An. Although being merged into Hanoi since 2008, Ha Tay was considered as a separate province to ensure the survey consistency.

4. In the case of Vietnam's SMEs under the SME Survey, we do not observe any issues of external equity from, such as the public markets (the initial public offerings) and/or organised private equity markets (venture capital). Thus, owner's equity in our study refers to internal equity, which is net worth or funding obtained from existing owners and stakeholders if any.

5. Firms are subject to credit constraints in the formal credit markets when they applied for loans and got rejected by the formal lenders, or whether they were rejected or not, they still demanded more credit (see more in, for example, Rand, 2007; Tran and Santarelli, 2013).

\section{References}

ADB (2013), Proposed Policy-Based Loan for Subprogram 2 Socialist Republic of Viet Nam: Second Small and Medium-Sized Enterprises Development Program, Report and Recommendation of the President to the Board of Directors, Project Number: 41360, Asian Development Bank, Manila.

ADB (2019), Asian Development Outlook 2019 Update: Fostering Growth and Inclusion in Asia's Cities, Asian Development Bank, Manila.

ADB (2018), Proposed Loan Joint Stock Commercial Bank for Investment and Development of Vietnam: Mainstreaming Small and Medium-Sized Enterprises Lending Project (Viet Nam), Asian Development Bank, Manila.

Archer, L.T. (2019), "Formality and financing patterns of small and medium-sized enterprises in Vietnam”, Emerging Markets Finance and Trade, pp. 1-18.

Atieno, R. (2009), Linkages, Access to Finance and the Performance of Small-Scale Enterprises in Kenya, Research paper No. 2009.06/UNU-WIDER.

Barslund, M. and Tarp, F. (2008), "Formal and informal rural credit in four provinces of Vietnam", The Journal of Development Studies, Vol. 44 No. 4, pp. 485-503.

Baum, C., Schaffer, M. and Stillman, S. (2007), IVENDOG: Stata Module to Calculate Durbin-WuHausman Endogeneity Test after Ivreg, Boston College Department of Economics.

Beck, T. (2007), "Financing constraints of SMEs in developing countries: evidence, determinants and solutions", KDI 36th Anniversary International Conference, pp. 26-27.

Beck, T., Demirgüç-Kunt, A. and Maksimovic, V. (2008), "Financing patterns around the world: are small firms different?”, Journal of Financial Economics, Vol. 89 No. 3, pp. 467-487.

Breusch, T., Ward, M.B., Nguyen, H.T.M. and Kompas, T. (2011), "On the fixed-effects vector decomposition", Political Analysis, Vol. 19 No. 2, pp. 123-134.

Butler, A.W., Fauver, L. and Mortal, S. (2009), "Corruption, political connections, and municipal finance", The Review of Financial Studies, Vol. 22 No. 7, pp. 2873-2905.

Chang, C., Chen, X. and Liao, G. (2014), "What are the reliably important determinants of capital structure in China?”, Pacific-Basin Finance Journal, Vol. 30, pp. 87-113. 
JED

22,2

CIEM (2014), Characteristics of the Vietnamese Business Environment: Evidence from the SME Survey in 2013, Central Institute for Economic Management, Hanoi.

Ciocchini, F., Durbin, E. and Ng, D.T. (2003), "Does corruption increase emerging market bond spreads?", Journal of Economics and Business, Vol. 55 Nos 5-6, pp. 503-528.

De Jong, A., Kabir, R. and Nguyen, T.T. (2008), "Capital structure around the world: the roles of firmand country-specific determinants", Journal of Banking and Finance, Vol. 32 No. 9, pp. 1954-1969.

Du, J. (2008), "Corruption and corporate finance patterns: an international perspective", Pacific Economic Review, Vol. 13 No. 2, pp. 183-208.

Fan, J.P., Titman, S. and Twite, G. (2012), "An international comparison of capital structure and debt maturity choices", Journal of Financial and Quantitative Analysis, Vol. 47 No. 1, pp. 23-56.

Foellmi, R. and Oechslin, M. (2007), "Who gains from non-collusive corruption?", Journal of Development Economics, Vol. 82 No. 1, pp. 95-119.

Harris, M. and Raviv, A. (1991), "The theory of capital structure", The Journal of Finance, Vol. 46 No. 1, pp. 297-355.

Jain, P.K., Kuvvet, E. and Pagano, M.S. (2017), “Corruption's impact on foreign portfolio investment”, International Business Review, Vol. 26 No. 1, pp. 23-35.

Johnson, S. and Mitton, T. (2003), "Cronyism and capital controls: evidence from Malaysia", Journal of Financial Economics, Vol. 67 No. 2, pp. 351-382.

Le, T.N.B. (2016), "The effect of taxation and corruption on firm growth: an empirical investigation for Vietnam", Journal of Economics and Development, Vol. 18 No. 3, pp. 5-29.

Lemma, T.T. (2015), "Corruption, debt financing and corporate ownership", Journal of Economic Studies, Vol. 42 No. 3, pp. 433-461.

Liu, Q., Lu, R. and Ma, X. (2015), “Corruption, financial resources and exports”, Review of International Economics, Vol. 23 No. 5, pp. 1023-1043.

Luo, Y. (2005), “An organizational perspective of corruption”, Management and Organization Review, Vol. 1 No. 1, pp. 119-154.

Mehnaz, S. and Wimpey, J. (2007), "When do enterprises prefer informal credit?", World Bank Policy Research Working Paper, No. 4435.

Myers, S.C. (1984), “The capital structure puzzle”, The Journal of Finance, Vol. 39 No. 3, pp. 574-592.

Nguyen, T.L. and Phan, H.M. (2015), "Above-average debt ratio and the relationship with return on equity: the case of the Vietnamese listed seafood enterprises", Journal of Economics and Development, Vol. 17 No. 1, pp. 50-74.

Nguyen, T.H.T. and To, T.T. (2019), "Determinants of the accessibility of Vietnamese enterprises to capital from banks and credit institutions", Journal of Economics and Development, Vol. 21, pp. 81-95.

Nguyen, T.L., Phan, H.M. and Bui, B.K. (2016), "Liabilities and the impacts on financial performance of the Vietnamese listed small and medium-sized enterprises", Journal of Economics and Development, Vol. 18 No. 3, pp. 41-63.

Nguyen, L.T., Hoai Nguyen, A.P., Van Passel, S., Azadi, H. and Lebailly, P. (2018), "Access to preferential loans for poverty reduction and rural development: evidence from Vietnam", Journal of Economic Issues, Vol. 52 No. 1, pp. 246-269.

Oncioiu, I. (2012), "Small and medium enterprises' access to financing - a European concern: evidence from Romanian SME", International Business Research, Vol. 5 No. 8, pp. 47-58.

$\mathrm{Ou}, \mathrm{C}$. and Haynes, G.W. (2006), "Acquisition of additional equity capital by small firms-findings from the national survey of small business finances", Small Business Economics, Vol. 27 No. 2-3, pp. 157-168.

Pham, T. and Talavera, O. (2018), "Discrimination, social capital, and financial constraints: the case of Viet Nam", World Development, Vol. 102, pp. 228-242. 
Rahaman, M.M. (2011), “Access to financing and firm growth”, Journal of Banking and Finance, Vol. 35 No. 3, pp. 709-723.

Rajan, R.G. and Zingales, L. (1995), "What do we know about capital structure? Some evidence from international data", The Journal of Finance, Vol. 50 No. 5, pp. 1421-1460.

Corruption and SME financing structure

Rand, J. (2007), "Credit constraints and determinants of the cost of capital in Vietnamese manufacturing", Small Business Economics, Vol. 29 Nos 1-2, pp. 1-13.

Rand, J. and Tarp, F. (2012), "Firm-level corruption in Vietnam", Economic Development and Cultural Change, Vol. 60 No. 3, pp. 571-595.

Rand, J. and Torm, N. (2012), "The benefits of formalization: evidence from Vietnamese manufacturing SMEs", World Development, Vol. 40 No. 5, pp. 983-998.

Tonoyan, V., Strohmeyer, R., Habib, M. and Perlitz, M. (2010), "Corruption and entrepreneurship: how formal and informal institutions shape small firm behaviour in transition and mature market economies”, Entrepreneurship: Theory and Practice, Vol. 34 No. 5, pp. 803-832.

Tran, H.T. and Santarelli, E. (2013), "Capital constraints and the performance of entrepreneurial firms in Vietnam", Industrial and Corporate Change, Vol. 23 No. 3, pp. 827-864.

Van Vu, H., Tran, T.Q., Van Nguyen, T. and Lim, S. (2018), "Corruption, types of corruption and firm financial performance: new evidence from a transitional economy", Journal of Business Ethics, Vol. 148 No. 4, pp. 847-858.

Vial, V. and Hanoteau, J. (2010), "Corruption, manufacturing plant growth, and the Asian paradox: Indonesian evidence", World Development, Vol. 38 No. 5, pp. 693-705.

Wang, Y. and You, J. (2012), "Corruption and firm growth: evidence from China", China Economic Review, Vol. 23 No. 2, pp. 415-433.

Whited, T.M. and Wu, G. (2006), "Financial constraints risk", The Review of Financial Studies, Vol. 19 No. 2, pp. 531-559.

Wooldridge, J.M. (2010), Econometric Analysis of Cross Section and Panel Data, MIT Press.

World Bank (2016), Vietnam 2035: Toward Prosperity, Creativity, Equity, and Democracy, World Bank, Washington, DC.

\section{Corresponding author}

Lan Archer can be contacted at: lan.nguyen4@griffithuni.edu.au

For instructions on how to order reprints of this article, please visit our website:

www.emeraldgrouppublishing.com/licensing/reprints.htm

Or contact us for further details: permissions@emeraldinsight.com 